\title{
Proactive Innovative Strategy
}

\author{
Jindra Peterková, Veronika Gruberová \\ Technical University of Ostrava, Ostrava, Czech Republic
}

\begin{abstract}
Innovative proactive strategies are presumption for obtaining of significant market position in comparison with the competition. The presumption consists in external entrepreneurial environment signals perception and evolution of entrepreneurial innovative potential at the same time. It stands to reason that it isn't enough to anticipate the strategic stamps of competitors, but it is necessary to build and evolve the innovative potential of firm too. The innovative level of potential is qualified from different points of view of enterprise functioning. But the implementation of innovation isn't only one of business activities, it is a systematically realized group of activities in order to increase of enterprise's efficiency. We can present the time behavior of every innovation through a sinusoid like an innovation cycle of this innovation. The position of firm is at the same time influenced with the choice of scientific-technological strategy, either offensive strategy producing the technical progress, or defensive strategy which consumes the strategic progress and participates in his mass diffusion. It is necessary to continuously innovate the current methods and processes to reach the competitive advantage thereby there is created an innovative flow. The aim of this paper is to highlight the importance of innovative potentials for the strategic management of firm. In this paper there will be judged the trend of innovative cycles in chosen industrial enterprises and evaluated the science-technological strategy of these enterprises. There will be charted types of innovations on the sample of 27 countries of EU according to the OECD classification of innovations and current methods of evaluation on innovative firms too. Consequently there will be delimitated possibilities of realization of offensive or defensive strategies for technical innovation. As a result there will be introduced a practical sample of innovative strategy of firm Linet.
\end{abstract}

Keywords: proactive strategy, innovation, innovative potential, innovation cycle

\section{Introduction to Problems}

The strengthening competitive fight evoked with the hyper competition and globalization in entrepreneurial environment urge entrepreneurial subjects to change their business strategy which is oriented to quality and price to business strategy based on innovations. Earlier going businesses find that they can fumble with considerable living problems during in applying of current strategies. There can come to cost reduction, impeding of production and in some cases to cancellation of whole workplaces. It is necessary to stop rely on

Jindra Peterková, Ph.D. of Economics, Faculty of Economics, Business Administration Department, Technical University of Ostrava.

Veronika Gruberová, Ph.D. candidate, Faculty of Economics, Business Administration Department, Technical University of Ostrava.

Correspondence concerning this article should be addressed to Jindra Peterková, Technical University of Ostrava, Faculty of Economics, Sokolská tř́da 33, Ostrava 70200, Czech Republic. E-mail: jindra.peterkova@vsb.cz. 
the size of entrepreneurial unit, size of market share or another competitive advantages obtaining in the past to prevent the critical scenarios because there isn't possible in this turbulent time to keep any competitive advantage in the long term. So it's necessary to start pay considerable attention to strengthen the competitiveness through entrepreneurial innovative activities. To become the best in the marketplace it isn't enough for the enterprise to obtain the leadership in this marketplace. The key to obtaining the dominance on the market is in continuous necessity to innovate the existing methods and processes, to be before others.

In accordance with authors (Doz \& Kosonen, 2011) there must be firms oppose the real challenge in form of speed and complication of system changes in partial branches of industry. As a branch of fast changes we can consider informational and communication technologies. The significant transformation originates in branch of health care. The reason of changes in these two branches are new science pieces of knowledge at most. Less changes we can record in branch of nutrition and food accessories, branch of pharmaceuticals without the prescription, branch of up keeping of fitness. Some branches of industry are still waiting for these changes - for example the energy industries with reference to power sawing and car industry with reference to the growth of fuel prices and global warming. On the other hand there exist branches which go through the principle but slow change, for example system of control, reporter or weapons systems. Despite their technological complexity there is the change reached slowly.

The new accesses for entrepreneurial strategies we can characterize like a transition from reactive to proactive strategies. The reactive strategies are based on analysis of competitive conditions and profit-oriented strategic plans. The principle is SWOT analysis which results from what is now and find how to improve. Consequently there is defined some competitive advantages. On the other hand the proactive strategy focused on change the competitive space in which is the firm situated or in which the firm pursues the creating quite new space for satisfaction of unknown need so far. They are strategies resulting from innovative potential.

Besides this the proactive strategy can encounter the delimitation of dynamic strategy too. It means the ability to change its strategy thereby obtain the lead before the competition. According to Doz and Kosonen (2011) the base is in strategic agility which is qualified with three dimensions: strategic sensibility, integrated group participation and flexibility of resources. Assumption of these competences makes it possible to ensure and keep the grow potential.

Business strategy based on innovative potential is the presumption to reach the competitive advantage in the chosen market. The aim of this paper is in examination of creation of entrepreneurial strategy based on innovative potential of firm but not from the side of its strategic advantage which is reset of ex post analysis these all applied on the example of concrete firm.

\section{Entrepreneurial Strategy Based on Innovative Potential}

The successful realization of chosen kind of innovation depends (Peterková \& Gruberová, 2011) on range of conditions and presumptions which change over time. One of the main conditions is existence of innovative potential. The innovative potential poses the potential of change, one of competitive potentials empowering mechanism of mobility (Mikoláš, 2005). This potential displays "the general qualification of enterprise for success, permanent pursuance of own vision" (Pittner \& Švejda, 2004). The fruitfulness of innovation requires "this potential to have high innovative level and create a spine of comprehensive effectively functioning 
proinnovative enterprise system" (Švejda, 2004). The innovative level of potential is judged from different points of view of functioning of enterprise namely in light of technical and technological (use of high tech, new effective technologies etc.), material equipment (use of intelligent multifunctional materials, recyclable materials etc.), economical and financial (for example efficiency of spent financial sources or sources of financing of innovative plan), business activity and marketing (for example ability to sell customers, forms of promotion), $R \& D$ (for example investment range to $\mathrm{R} \& \mathrm{D}$, quantity of inventive stimulations for innovations), social (for example quality of relations inside the firm, way of remuneration and motivation of employees) and management above all the ability to provide for development of innovative potential (Pittner \& Švejda, 2004).

One of accesses which comprise the innovative potential is the access of Kiernan. He sees the competitive advantage of firm in the innovative potential. The point of departure for formulation of 11 commencement for obtaining of future competitiveness is so-called iceberg balance of potential value (see Figure 1) and an innovative infrastructure of firm.

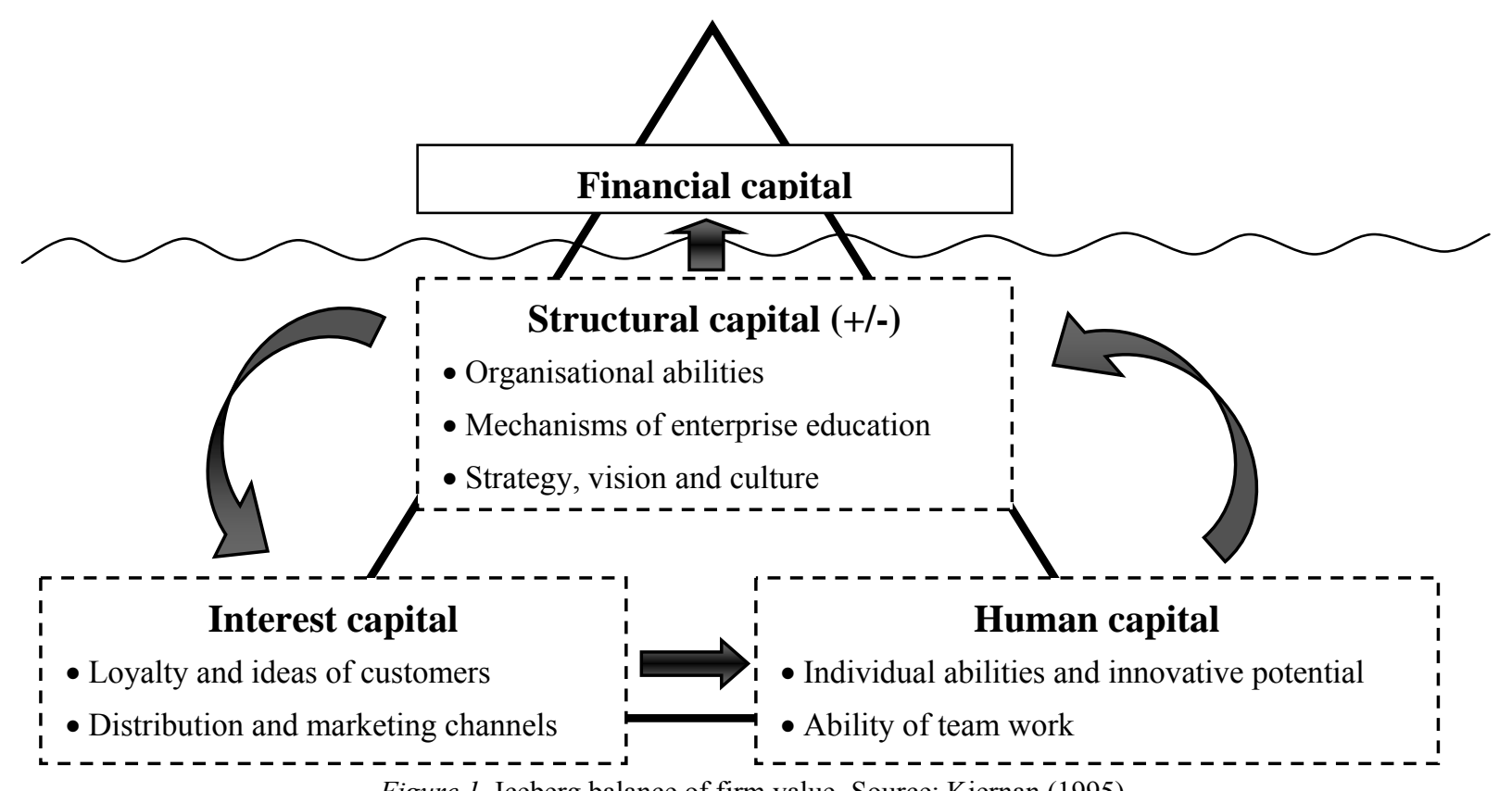

Figure 1. Iceberg balance of firm value. Source: Kiernan (1995).

The potential value of company he compares to iceberg where only 10 percent sticks out of the water surface and remaining 90 percent of the iceberg he calls intellectual capital base of company. It is formed from three elements:

- human capital (skills, knowledge, values and innovative potential of individuals in the firm, ability of team work);

- special-interest capital (distributional and marketing channels, network of strategic allies and partners, loyalty and customers' ideas);

- structural capital (innovative and educational potential of enterprise, ability of team work, strategy, vision, culture, informational systems and numberless another intangible elements which are the real source of creating of value and of comparative benefits). The structural capital is a tool which connects human and special-interest potential and which equalizes and finally transforms these potentials to the financial capital and profit. The 
structure capital can increase or decrease the intellectual capital base. So it's called an innovative infrastructure of firm.

The approach considering the innovative potential to be a basis of competitiveness is a conception of Senge too. He elaborated the theory of learning organization whose functioning is based on application of five disciplines ${ }^{1}$. The determined disciplines (Schwalbe, 2007) shall help to evolving abilities and skills which run the learning cycle. They are:

- personal championship representative ability to create calculated results during an exercise of acceptable effort;

- mental models reflective opinion notions or images of perceived world;

- team learning whose base is a dialog if you like ability of team members to put away all presumptions and to begin the real collective thought;

- creating of collectively shared vision takes effect in that people excel and learn because they want not must;

- system thinking isn't concentrated on the basic building blocks but rather on basic principles of organization. To understand these things in the system sense means to place them to the context, determine the character of their relations. The unit is more than the sum of its parts.

\section{Characteristic and Classification of Innovations}

Innovations preset "a specific instrument of entrepreneurs, a tool with which we can use changes like opportunities for business in different area or in rendition of different services" (Drucker, 2007). Under the term innovation according to J. A. Schumpeter we can find "an evolutionary form of invention which is ready to be produced and sold on the market" (Keklik, 2003), so an introduction of new product, technology, technological change in production of already existing products, an assignment of new markets or new assistant sources or an introduction of new organization. But currently the most widespread and in the framework of European Union the most widely used is definition resulting from document of European committee COM (2003) 112 where is:

The innovation a resumption and enlargement of scale of products and services and accompanying markets, a creation of new methods of production, supplies and distribution, an introduction of management changes, an organization of work, working conditions and qualification of work force.

According to Švejda (2004), there plays an important role creativity, invention and innovation. He says:

The substance of creativity is in ability of man to create values. It has two interdependent relative independent aspects. Partly a cognitional, gnoseological aspect which is liked with existence of rational activity and with ability to think up new opinions, ideas, theories, artistic or scientific etc. and partly an aspect oriented to creation of values from practical viewpoint-implementing. (Švejda, 2004)

On the other hand the invention is closely linked with the cognitional aspect of creation and it's based on new ideas, ingenuity and mind inventiveness. The intuition is complementary to these three building stones of innovation: Intuition in mental suggestion, illumination or occasional intuition which assists the striking to heart of problem. From the point of view of level of degression of novelty we can distinguish these four basic sources of innovation: acceptance, imitation, adaptation and absolute invention (Štrach, 2009).

But the innovation isn't an unified change. In the framework of this paper we appeal from next two methods

${ }^{1}$ The discipline is a set of theories and methods which are necessary to study and master them to be apply in practice. 
of classification of innovations. The first of them is based on the degree of innovation so the measure of affinity or on the contrary on relation of products (see Table 1).

Table 1

Diagram of Degression of Innovation (Valenta, 1969, 2004)

\begin{tabular}{|l|l|l|}
\hline Degree & Mark & What will change \\
\hline$n$ & degeneration innovation & decrease of features, spontaneous changes \\
\hline 0 & regeneration innovation & returning of structure to the original condition aimed at overcoming of trend to degeneration \\
\hline 1 & quantitative innovation & $\begin{array}{l}\text { increase of frequency of elementary changes = necessary and long term process of internal } \\
\text { adaptation }\end{array}$ \\
\hline 2 & organizational innovation & regrouping of elementary components and relations among them \\
\hline 3 & $\begin{array}{l}\text { qualitative innovation } \\
\text {-adaptation change }\end{array}$ & applying of progress in interaction of material factors and human qualification \\
\hline 4 & - functional change & entry of new variety, the attention is paid to product solution \\
\hline 5 & -creation of new variety & $\begin{array}{l}\text { overcoming of several parameters and functional proprieties, original conception is } \\
\text { conserved }\end{array}$ \\
\hline 6 & -change of conception & overcoming of parameters and constructional and functional conceptions \\
\hline 7 & specific innovation & change of constructional conception \\
\hline 8 & generic innovation & change of principle of used technology \\
\hline 9 & essential innovation & change of access to environment \\
\hline
\end{tabular}

The second kind of classification which is used for purposes of this paper is classification according to manual OECD (Oslo manual, 2005). In this conception there are innovations divided to technical and nontechnical.

Technical innovations pose a performance of new products or an improvement already existing products (e.g., increase of quality) and services (= innovation of product), introduction of new production processes or use of new till unknown source of raw material or intermediate products (= innovation of process). As a nontechnical innovation there is classified obtaining of new market (= marketing innovation) or change in operating management or organization of production (= organizational innovation).

Despite of increasing sense of innovations in the entrepreneurial activities there is possible to find out from gained information on the basis of researched exponent of 27 EU countries (ČSÚ, 2010) that in most of countries there are predominate noninnovative enterprises over the innovative enterprises. According to analyzed dates from EUROSTAT there is about $40 \%$ of all entrepreneurial subjects considered to be innovative firm. It's necessary to mention that in this research there were classified only firms from manufacturing industry which have more than 10 employees. This fact isn't in some publications accented enough or it is totally failed (see paper "Six community innovation survey: More than half of EU27 enterprises are innovative"). If we would include all entrepreneurial subjects in this research we can find that the number of innovative firms will be only in the frame of percents or even tenths of percent. The presumption of choose of firm with more than 10 employees is in higher innovative potential of this firm. And in the framework of partial groups of enterprises there is proportion of innovative firms markedly different. Generally we can say that the bigger enterprise the higher is proportion of innovative firms in sum total of enterprises in a given group. In the concrete among enterprises with from 10 to 49 employees there is only about $34 \%$ of innovative firms in the framework of enterprises with from 50 to 249 employees increases this proportion to more than $50 \%$ and in the framework of enterprises with more than 250 employees is this proportion of innovative firms more than $70 \%$. 
Interestingly in the framework of Czech Republic dominate enterprise, with nontechnical innovations, whereas small firms focus on marketing innovations above all and on organizational innovations focus middle and big firms. In foreign corporations there obtain nontechnical innovation in the shape of organizational innovation too (see Table 2).

Table 2

The Level of Technical and Nontechnical Innovations in Czech Republic (ČSÚ, 2010)

\begin{tabular}{|c|c|c|c|c|}
\hline & \multicolumn{2}{|c|}{ Technical innovation } & \multicolumn{2}{|c|}{ Nontechnical innovation } \\
\hline & Innovation of product & Innovation of process & Marketing i. & Organizational i. \\
\hline Czech Republic in total & $18.4 \%$ & $24.7 \%$ & $32.1 \%$ & $29.2 \%$ \\
\hline \multicolumn{5}{|l|}{ According to the size of firm: } \\
\hline small (10-49 empl.) & $14.8 \%$ & $21.5 \%$ & $30.5 \%$ & $25.4 \%$ \\
\hline middle (50-249 empl.) & $27.2 \%$ & $32.0 \%$ & $36.1 \%$ & $39.7 \%$ \\
\hline big (250 and more empl.) & $49.5 \%$ & $53.3 \%$ & $44.2 \%$ & $56.4 \%$ \\
\hline \multicolumn{5}{|l|}{ According to the ownership: } \\
\hline domestic enterprises & $16.2 \%$ & $22.3 \%$ & $31.4 \%$ & $26.1 \%$ \\
\hline foreign enterprises & $29.0 \%$ & $36.4 \%$ & $35.4 \%$ & $44.2 \%$ \\
\hline
\end{tabular}

\section{Options of Measuring of Innovative Potential}

If we appear from the presumption that the base of competitive power isn't only the financial, business and procedural potential but above all the innovative potential it's necessary to ask the question how is the competitive force measured. In finding of answers there will be engaged created research team in our workplace which would realize a probe into the life of entrepreneurial activity of global firms (Peterková \& Franek, 2010).

The objective of research activities there would be to get some view of accesses and methods of measuring of competitive power of enterprise. For examination of accesses of measuring of competitive force there was realized a probe into entrepreneurial activities of 100 global firms acting in 19 branches of industry. The realization of probe proved that on the one side there is the evaluation of competitive power continuously identified with evaluation of productivity in entrepreneurial praxis. The productivity of enterprise is measured above all from the point of view of achieved efficiency of financial potential. It is assessment of competitive force from the point of view of past if you like from the point of view of result or in past achieved competitive power. On this access there are based all chart of TOP global firms (Ernst \& Young Top 300, Financial Times Global FT500, Forbes Global 2000, Fortune Global 500). But on the other hand there is effort to take down the influence of human, procedural (technological) potential through of partial indicators for example number or patents realized with the firm, share of spending on R\&D or through index of innovativeness. The index of innovativeness is created in cooperation with Boston consulting group. This method is based on evaluation of achieved financial results and on expert's evaluation of enterprises (CEO). The expert's evaluation has a stress of $80 \%$ and evaluation of financial factors only $20 \%$. So results are influenced with financial respect as well as with subjectively-objective evaluation CEO.

Results of this probe showed that good results are achieved in firms which don't underestimate their innovativeness, spending on R\&D and patents for example Samsung, General Electric, Intel, Toyota, Google. They are firms doing their business in branch of information technology and car industry. On the other hand firms 
which record only small financial results aren't on the first places, for example Royal Dutch, Wal-Mart etc.. They are doing their in branches of raw materials and business activities. Above all in the industrial branch of Oil and Gas there is evident that the competitive force is result of ownership of source of raw material. It turns out that the evaluation of competitive force must be realized from the point of view of evaluation of financial potential as well as from the point of view of human, procedural, business and innovative potential.

\section{Way of Evaluation of Innovative Firms}

At present, there exist different ways of evaluation of innovative firms. There set up, for example, a chart of the fifty most innovative firms, created with Journal Fast Company which addresses innovations in the branch of technologies, ethics of economy, management and design. It is the chart of TOP 50 most innovative firms in chosen branches including energetic, information technologies, internet, biomedicine and materials. Every firm is judged by three criteria: business model, strategy of implementation and diffusion of technologies and probability of success. In current year (2011), there are gaining ground firms which were on rear positions in this chart. According to Prahalad it is the principle of success of these firms in ambitions of firm and subsequent diffusion of sources' background. The most innovative firms are characterized with a quite new business (new kind of business) which haven't been presented yet, they create a new framework of use of some findings or invention and new models of market (for example business and entrepreneurial models). The sequence of firms in this chart of TOP 50 is shown in Table 3.

Table 3

Short List of First 10 Firms From TOP 50 Firms (Innovation Policy, 2003)

\begin{tabular}{|l|l|l|l|}
\hline List of firms & Sequence 2011 & Sequence 2010 & Way of innovation \\
\hline Apple & 1 & 3 & For dominating the business landscape, in 101 ways \\
\hline Twitter & 2 & 50 & $\begin{array}{l}\text { For 5 years of explosive growth that have redefined } \\
\text { communication }\end{array}$ \\
\hline Facebook & 3 & 1 & For 600 million users, despite Hollywood \\
\hline Nissan & 4 & - & For creating the Leaf, the first mass-market all electric car \\
\hline Groupon & 5 (new in list) & - & For reinvigorating retail, and turning down \$6 billion \\
\hline Google & 6 & 4 & For instantly upgrading the search experience \\
\hline Dawning Information Industry & 7 (new in list) & - & For building the world's fastest supercomputer \\
\hline Netflix & 8 (new in list) & - & $\begin{array}{l}\text { For streaming itself into a \$ 9 billion powerhouse (and } \\
\text { crushing Blockbuster) }\end{array}$ \\
\hline Zynga & 9 & 33 & For being the \$ 500 million alpha dog of social gaming \\
\hline Epocrates & 10 & 12 & For giving doctors and nurses instant drug reference \\
\hline
\end{tabular}

The sequence of the most innovative firms is changing in accordance with the chosen chart criteria. This implies that there is a different evaluation in chart of the 100 most innovative firms (The World's Most Innovative Companies).

In every firm there is projected the future income (cash flow) from current business plus expected grow on the basis of current position at first. This income is counted to net present value. This value is consequently compared with the current market value of firm. The amount with which is the market value higher than the current value of cash flow presents the premium additional charge from reached innovation.

The Innovation Premium is a measure of how much investors have bid up the stock price of a company above the value of its existing business based on expectations of future innovative results (new products, services 
and markets). Members of the list must have $\$ 10$ billion in market capitalization, spend at least $1 \%$ of their asset base on R\&D and have seven years of public data.

Except dates introduce in EUROSTAT and statistics executed with Czech statistical office there are concerned with analysis of innovative firms in Czech Republic Agency of innovative entrepreneurship. This agency takes example of definition of innovative firm in the National innovative strategy of Czech Republic from March 24, 2004 which is: The innovative firm is generally a small and middle firm whose main subject of enterprise is to realize a project of new product to commercial age and to place it on the market. The range of surveyed firms as evidenced with this definition is confined to small and middle firms and it's cramped to innovations of product.

\section{Types of Innovative Strategies Based on Technical Innovations}

In the event that the firm has technical innovation it can realized two types of innovative strategies. According to Slávik (1999) the realization of innovative business strategy influences the technical level of realized products and technologies. Whereas the technical level is influenced with originality and newness of technical innovations. The firm can invoke ether offensive or defensive strategy. The firm which is an initiator of offensive strategy is an initiator of technical improvement and it sets the trend of technical development of whole branch. On the other hand, the firm asserting the defensive strategy makes use of results of technical improvement and ensure its diffusion. The type of used strategy is dependent upon the entrepreneurial power of producer and upon the attractively of branch. The growth of entrepreneurial force of producer and the attractively of branch makes it possible to realize the offensive strategy and vice versa loss of entrepreneurial force and attractively of branch rather urge firms to invoke the defensive strategy.

To the group of offensive strategies according to Slávik (1999) is ranged a front-end and an adaptive strategy. The front-end strategy is typical for innovative leader on the market in particular industrial branch which produces a product on the top technical level which is destined only for particular customer segment. In the case of adaptive strategy of firm it can produce a product on Loir technical level and it focuses on a broad group of customers. This strategy is realized with firms which want to forbear the risk related to high spending on research and development of new products or processes. They adapt and make up results of innovative leader and derive it for their own benefit. The offensive strategy is realized above all in global pilot enterprises which have character of transnational firms. They bear their activities on their own research and development and support of scientific-technological parks and universities.

The second group of defensive strategies is formed with imitative, license and accepting strategy. The imitative strategy is based on fast imitation of results of global pilot enterprises realized a top and an adaptive strategy. It is the imitation of results for different segments of customers or the imitation subsisting in lower production spendings etc.. Firms in this strategy produce products with standard or substandard quality. It can become that the imitation can improve the original innovation. This strategy is elected with firms which haven't strong research and development. The enterprise which have no research and development favors the license strategy. Peking is the results of research and development for a fee for example a franchise. The use of this strategy can lead to technical backwardness of firm. The enterprise which finally takes up products and technologies of produces which leaved the market to meet another demand realize the accepting strategy. This 
strategy poses for the enterprise a strategy of innovative lag. The defensive strategy is realized generally in satellite firms which haven't strong or even no research and development background. The accepting strategy is realized often in firms of types entprepreneur-selfemployer.

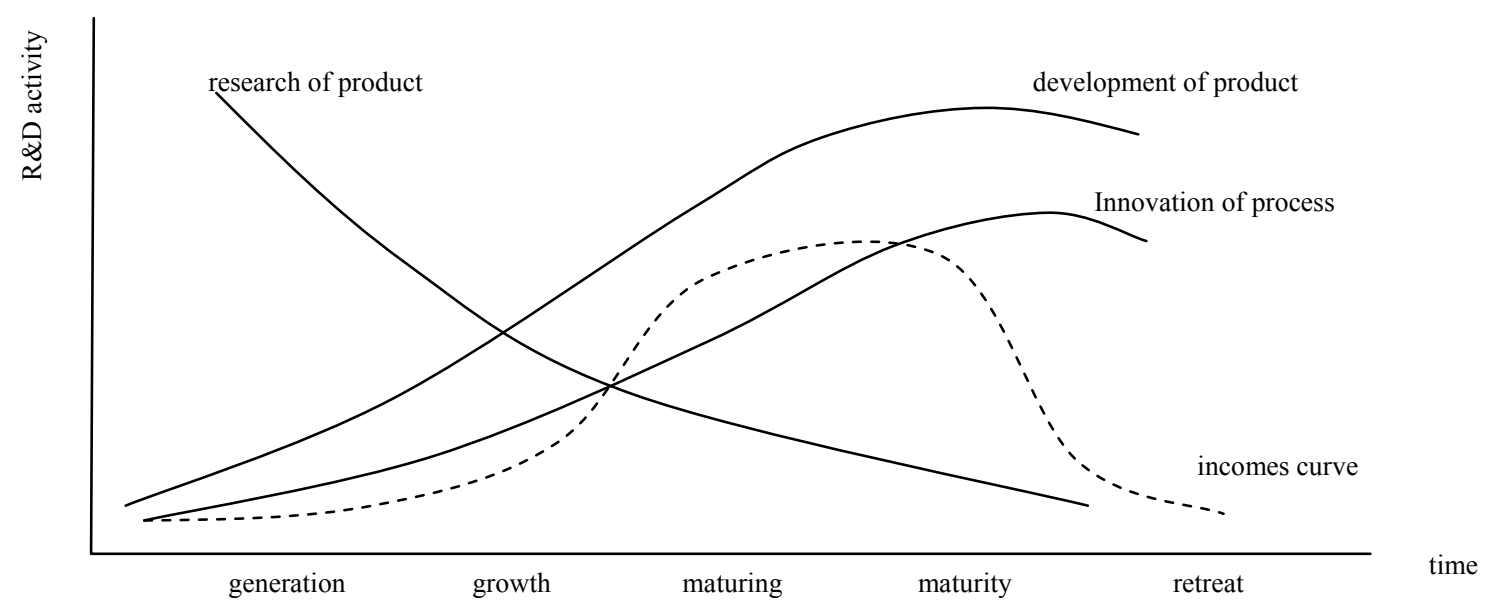

Figure 2. Lifecycle of firm and its R\&D activities. Source: Slávik (1999, p. 216).

Slávik (1999) presents that research and development activities of firm are influenced with the life cycle of firm. In the initial stage of life cycle, it is firm developer on the base of applied and basic research. After some time, it is the original knowledge potential spent and another research can meet the knowledge limit in the framework of some fading. Continuing of the research is realized in the way of existing fading and user possibilities (see Figure 2).

From the view of realized strategy (firs moving or following) and from the view of plain strategy description, of value creation Afuah (2009) divides firms to four groups: firms of Stars type, firms of Explorer type, firms of Exploiter type and firms of Me-too type (see Figure 3).

According to this classification the clearest strategy of value creation and strategy of first moving have firms of Stars type. The same strategy of first draw have firms explorer type too, but they have one absence consisting in fortunately of realized activities. Firms of Exploiter and Me-too types realize strategy of following, they are waiting for decline of technological and market incertitude. And firms of Me-too type haven't a clear strategy.

\begin{tabular}{|c|c|c|c|}
\hline \multirow{2}{*}{ : } & First mover & EXPLORER & "SUPERSTAR \\
\hline & Follower & ME-TOO & EXPLOITER \\
\hline & & NO & YES \\
\hline
\end{tabular}

Figure 3. Types of realized innovations. Source: Afuah (2009).

\section{Practical Example of Innovative Business of Firm Linet}

For evaluation of innovative strategy there was chosen Czech firm Linet ČR, global firm with activities in 25 countries and with amount of turnover of 1.7 milliard. This firm is ranked among leaders on the market of clinical beds. It is a producer applying technical innovation of product in the form of a new system of lifting of clinical 
beds. The innovative strategy in the line of products ELEGANZA is evaluated through the life cycle.

\section{Characteristics of Innovative Business Activity of Firm Linet}

The firm Linet $\breve{C} R$ is a producer of special equipment destined for hospitals, rest homes or home care, especially the positioning beds. In its branch, this firm belongs amount the most dynamically developing firms in Europe. This firm is through of world leader of innovative solving for health and nursing technology and at it group the pendant the biggest producers of clinical beds all over the world of the same time.

This firm started its business in 1990 with the aim of building up a modern clinical beds plant which is going successfully well. In 1992 this firm already realized its first big contracts and in 1994 it build up its own developing department. Thanks to enlargement of factory building it was able to produce in 1998 already 10,000 pieces of products and thanks to quality of its products this firm obtained the certification of ISO 9001 EN 46,001. In 1999, the firm developed a new system of lifting of clinical beds which applied already in production of new type of beds ELEGANZA and Multicare in 2000. Thanks the quality of its products and at the same time with the individuality of firm this firm exported in the next year already to 25 countries.

At present the firm exports its products to 75 countries of world whereas the key market stays in Europe with the share of export of production of $74 \%$. The next engaged markets are in Latin America with $14 \%$ share of export of firm production, Middle East with $10 \%$ and Asia with $2 \%$. The total export of production presents $81 \%$. The remaining volume of production is seen on the market in Czech Republic and in Slovakia.

\section{Life Cycle of Innovative Activity of Firm Linet}

For display of the life cycle of innovative activity of firm Linet we focused on clinical beds of line ELEGANZA whose production represents at present almost $50 \%$ of volume of production of whole firm. For confrontation there are stated total earnings of firm (see Figure 4).

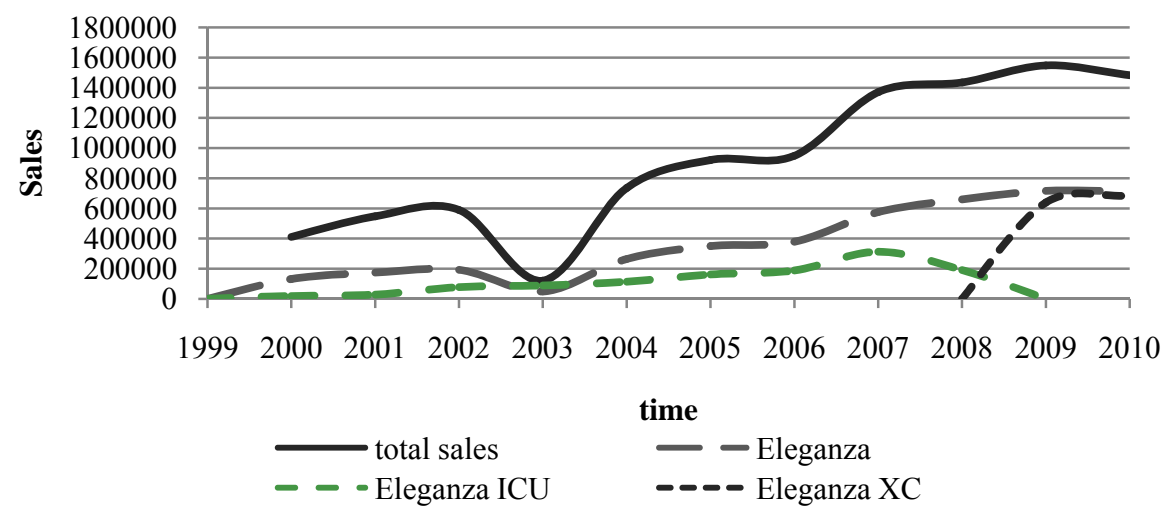

Figure 4. Lifecycle of innovation activity of firm Linet (annual reports of Linet).

In the picture there is evident an upward trend of earnings which comes from fruitfulness of firm on the market. The slump in earnings is evident only in 2003. This slump caused with continuing recession in branch of production which is showed up in sharping of competitive fight and in expressive pressure for price reduction. The same growth trend has earnings form sale of the most considerable products of line ELEGANZA too. These products were placed on the market in 1999 and already in next year they achieved $32 \%$ of total production with 3,964 produced pieces. At present their share on production is over $46 \%$ and in 2010 there were produces almost 
23,000 of this product.

Regarding to the fact that the firm is continuously innovating its production we chose to illustrate the innovative cycle of product ELEGANZA ICU. This product is ranked among the most considerable line of products ELEGANZA. Despite of the low share on volume of production (only $2 \%$ of total production of line ELEGANZA) this produce a participant in whole $32 \%$ of earnings of line ELEGANZA. The introduction of product on the market was in the same year like the introduction of the whole line ELEGANZA. As evidenced by the picture, the progress of earnings grew until 2007. In 2008, there finished the development of product ELEGANZA XC which is an improvement of ELEGANZA ICU. So in 2009 the production of ELEGANYA ICU was stopped and at present there is offered only the innovated variation ELEGANZA XC.

\section{Conclusion}

From before-mentioned analysis of innovative activity of firm Linet we can judge that the firm implements a front-end innovative strategy. It is given with the position of firm on the market of clinical beds and the use of original technical innovation of product. Lined could develop the clinical bed which can move in few seconds to medical table on which can be the patient weighted or radiograped. The bed relieves every manipulation with the patient. From the view of Afuah (2009) we put this firm class to the group of Stars type firm, it means that this firm has clearly defined strategy, and it implements the strategy of stroke. Linet established itself in inland and foreign trade too.

From the curve of life cycle of innovative activity it is possible to derive particular steps of innovation of product ELEGANZA. On the entering to the market the innovation of product of firm Linet based above all of the basic research, later after the remedy of shortage the firm hit against the knowledge limit in the area of system of lifting and consequently the last innovative step in research with the view of modification of products in the shape of introduction of new product ELEGENZA XC. It turns that the proactive strategy based on innovative potential is the basis of competitive advantage of firm on chosen market.

It turns out that the proactive strategy based on innovative potential is the principle of competitive advantage of firm on several markets. It is found that in the framework of development of innovative potential enterprises focus on nontechnical innovations which relate to realization above all the marketing and organizational innovations. For obtaining the position of innovative leader it's necessary to realize the technical innovation. With the application of technical innovations, the firm goes to choose reasonable offensive or defensive innovative strategy. Through the probe into the life of global entrepreneurial subjects there was verified on the basis of the sample of 100 global firms doing their business in 19 branches that good results are achieved in firms which don't downgrade their innovativeness, expenditures to research and development and patents. The evaluation of innovative enterprises isn't unifies and it differentiate according to chosen criteria. The concrete evaluation of innovative activities in the framework of business strategy is realized in firm Linet through the life cycle of product line ELEGANZA.

The concrete evaluation of innovative activities in the frame of business strategy was realized in the firm Linet through the lifecycle of product line ELEGANZA. The above-mentioned analysis shows the innovative strategy of firm which reflects realization of innovations in the framework of the product line ELEGANZA. This firm pursues to overtake its competition and to satisfy the customer through technically unique clinical beds. 


\section{References}

Afuah, A. (2009). Strategic innovation: New game strategies. UK: Taylor \& Francis e-Library Annual report of firm Linet.

Bilton, C. H., \& Cummings, S. (2010). Creative strategy. United Kingdom: Johny Wiley \& Sons Ltd..

COM. (2003). Innovation policy: Updating the Union's approach in the context of the Lisbon strategy, 112.

Drucker, P. F. (2007). Innovation and entrepreneurship. Oxford: Fast company: \#21 Gilt Group.

Keklik. M. (2003). Schumpeter, innovation and growth: Long-cycle dynamics in the post. Hampshire: A. Publishing Limited.

Kiernan, J. M. (1995). Get innovative or get dead. Diane Pub Co..

Mikoláš, Z. (2005). How to increase a firm competitiveness. Praha: Grada Publishing.

National innovative strategy of Czech Republic. (2004). OECD: Oslo Manual. Guidelines for Collecting and Interpreting Innovation Data. OECD 2005.

Peterková, J., \& Franek, J. (2010). Competitive power as a basis of the development of enterprises potential. Warszawa: ICAN Spólka z ograniczona odpowiedzialnóscia Sp.k. (Harvard Business Review Ploska).

Peterková, J., \& Gruberová, V. (2010). Competitiveness of firm based on its innovative potential. Athens, Greece: Eurasia Business and Economics Society.

Pittner, M., \& Švejda, P. (2004). Řizení inovací v podniku. Praha: AIP ČR.

Prahalad, C. K., \& Ramaswamy, V. (2005). The future of competition. Co-creating unique value with customers. Praha: Management Press.

Schwalbe, K. (2007). Project engineering in IT. Brno: Computer Press.

Slávik, S̆. (1999). Strategic management of firm. Bratislava: Sprint.

Štrach, P. (2009). International management. Praha: Grada Publishing.

Švejda, P. (2004). Innovative business. Praha: AIP ČR. 